\title{
Designing a model to estimate the impact and cost effectiveness of online learning platforms
}

\author{
Doris Verónica Meza- \\ Bolaños \\ Universidad Central del Ecuador \\ Quito Ecuador \\ 593987275000 \\ dmeza@uce.edu.ec
}

\author{
Patricia Compañ-Rosique \\ Dpto. Ciencia de la Computación e \\ Inteligencia Artificial \\ Universidad de Alicante España \\ +34965903400 \\ patricia.company@ua.es
}

\author{
Rosana Satorre-Cuerda \\ Dpto. Ciencia de la Computación e \\ Inteligencia Artificial \\ Universidad de Alicante España \\ +34965903400 \\ rosana.satorre@ua.es
}

\begin{abstract}
There are different methodologies that have attempted to measure profitability and impact of using online learning platforms, all of which focus on a set of quantifiable and nonquantifiable aspects. These methods consider different items from various perspectives. The purpose of this work is to assess each one and determine the suitable indicators applicable to the reality of higher education in Ecuador. A hybrid model with characteristics from different perspectives could be designed with these indicators.
\end{abstract}

\section{CCS Concepts}

- Evaluation $\rightarrow$ e-learning $\rightarrow$ ROI $\bullet$ Training $\rightarrow$ e-learning $\rightarrow$ $\mathrm{ROE} \quad$ Evaluation $\rightarrow$ e-learning $\rightarrow$ Metodology $\bullet$ Evaluation $\rightarrow$ e-learning $\rightarrow$ Models. $\bullet$ Elearning $\rightarrow$ mesurements $\rightarrow$ quality.

\section{Keywords}

e-learning; education; learning; knowledge, evaluation models.

\section{CONTEXT AND MOTIVATION THAT DRIVES THE DISSERTATION RESEARCH}

E-learning in recent years has become an important product in the information society and it has played a key role in the transformation of the models of teaching - learning. Its application has produced a major impact within higher education [1] because the models of teaching-learning are designed to make students improve their learning and participation, develop digital literacy skills and promote creativity, innovation and the ability of critical thinking.

Investing in such tools should be evaluated in monetary terms in order to present clear evidence of their effectiveness and their support in meeting the objectives of an institution.

The motivation to establish a metric on which to assess the impact of e-learning at the Ecuadorian state universities arises because it has been detected within the university a high dropout rate of students, high early leaving and few graduates, as well as high incidence of third enrolments, among other problems detected within the University.

State Universities of Ecuador, to be an integral part of the development of the society and the country, they have benefited from the investment made by the State in terms of improving the learning environment of students and implementing e-learning tools.

In this context, the State has sought to integrate technological support tools for both students and teachers into the production processes, in order to meet the quality parameters set by regulatory agencies. These organisms are driving excellence in higher education and improving teaching and learning processes.

The key aspect for the State is to provide appropriate tools that are aligned with its objectives and the objectives of each school, their careers or specialties. However, it is difficult for these institutions to find suitable metrics to determine the training effects. The common measure applied until now is related to the perceived student achievement through standardized tests in which the environment where learning takes place is not taken into account.

Generating tailored model also seeks to determine specific characteristics of how students learn through electronic means. These features will be decisive in improving learning outcomes later [2].

It is necessary to determine the quality, benefits and return on investment, in order to decide whether or not to continue investing in this kind of tools because there is not enough evidence in Ecuador of the added value generated by online working environments. Therefore, this research is focused on determining a set of appropriate indicators to help quantify the benefits of using e-learning tools.

\section{STATE OF THE ART}

Over time, many efforts have been made to perform the quantification of return and several methodologies have been developed to analyze of a number of factors that influence this quantification.

The classic financial method used for this purpose is the calculation of ROI or return on investment. ROI measures the return on investment, that is, how much profit the investment will produce to the company depending on the invested money.

A common way to do this is to compare income and expenses. The problem in education arises because there are many factors and subjective and complex characteristics to be quantified. Due to the complexity of this analysis, certain indicators that have been used are taken as the starting point for this research. They have been used in other models and they have been considered influential during the research. These indicators are: 
- Type of students and their skills,

- Learning styles and multiple intelligence,

- The obstacles they face in (e-learning barriers) e-learning,

- Available technical capabilities for users;

- Accessibility available to users

- Level of motivation,

- The attitudes and interests;

- Effectiveness of students in the e-learning environment.

- Learning outcomes. [3]

ROI is not the only method that can be used. Other evaluation models that have been very well received for this purpose are:

- HCTR model (Human Capital Training ROI): this methodology describes practical tools for evaluating training on two aspects: qualitative and financial.

- Kirkpatrick-Phillips model: it was the basis of HCTR. This model introduces the concept of ROE (return on expectation) as a way to assess the training based on aspects such as teamwork, learning outcomes, objectives of the institution and profitability, among others.

All these methods focus on showing the effectiveness of education, based on the use of new technologies. A factor to consider when applying this assessment is to determine from what perspective are the learning outcomes evaluated, since the performance measurement of the investment can change.

\section{Stoel and Van Leeuwen's Systemic Model}

Stoel and Van Leeuwen [4] value e-learning tools using ROI in order to determine how much added value generates this investment in relation to the financial sacrifice needed to make it profitable. This study is performed by an exhaustive breakdown of expenses and incomes that could be significant, expressed in figures. The method applied suggests a set of steps such as:

- Identify the actors within the chain in question (students, teachers, authorities, education center)

- Specify the profits of the different stakeholders and identify those actors that represent an expenditure

- Develop model and its possible generalization.

- Calculate the total income and expenses

- Calculate the ROI according to formula ((income expenditure) / expenditure) $* 100 \%$

- Present the results for each actor.

\section{Josep M. Duart's Systemic Model}

For Josep M. Duart [5], the ROI calculation needs a preliminary step: clearly define the objectives of the training action. It is considered that these objectives have a specific period of time to be fulfilled, they have a responsible for each one, and they are quantifiable.

\begin{tabular}{|c|l|l|l|l|}
\hline & Finality & $\begin{array}{l}\text { Training } \\
\text { objective }\end{array}$ & $\begin{array}{l}\text { Learning } \\
\text { objective }\end{array}$ & Means \\
\hline $\begin{array}{l}\text { Defin } \\
\text { ition }\end{array}$ & $\begin{array}{l}\text { Global } \\
\text { Vision about } \\
\text { training }\end{array}$ & $\begin{array}{l}\text { Specific } \\
\text { goal of } \\
\text { training }\end{array}$ & $\begin{array}{l}\text { Specific } \\
\text { personal } \\
\text { goal of } \\
\text { training }\end{array}$ & $\begin{array}{l}\text { Platform } \\
\text { for } \\
\text { training }\end{array}$ \\
\hline $\begin{array}{l}\text { Respon } \\
\text { sible }\end{array}$ & $\begin{array}{l}\text { Generic, } \\
\text { attributable to } \\
\text { the entire } \\
\text { organization }\end{array}$ & $\begin{array}{l}\text { Specific, } \\
\text { attributable } \\
\text { to a group } \\
\text { that has a }\end{array}$ & $\begin{array}{l}\text { Specific, } \\
\text { attributabl } \\
\text { e to a } \\
\text { person }\end{array}$ & \\
\hline
\end{tabular}

\begin{tabular}{|l|l|l|l|l|}
\hline $\begin{array}{l}\text { Time } \\
\text { Fram } \\
\text { e }\end{array}$ & $\begin{array}{l}\text { It can be } \\
\text { expressed in } \\
\text { time periods } \\
\text { (medium or } \\
\text { long term) }\end{array}$ & $\begin{array}{l}\text { It must be } \\
\text { expressed in } \\
\text { time periods } \\
\text { (short term) }\end{array}$ & $\begin{array}{l}\text { It must be } \\
\text { expressed } \\
\text { in time } \\
\text { periods } \\
\text { (short } \\
\text { term) }\end{array}$ & \\
\hline $\begin{array}{l}\text { Evalu } \\
\text { ation }\end{array}$ & $\begin{array}{l}\text { It may } \\
\text { include } \\
\text { qualitative } \\
\text { indicators of } \\
\text { evaluation }\end{array}$ & $\begin{array}{l}\text { It should } \\
\text { include } \\
\text { quantifiable } \\
\text { parameters } \\
\text { for assessing } \\
\text { the results }\end{array}$ & $\begin{array}{l}\text { It should } \\
\text { include } \\
\text { quantifiab } \\
\text { le parameter } \\
\text { parible for } \\
\text { sasessing } \\
\text { the results }\end{array}$ & \\
\hline
\end{tabular}

Table 1. Valuation Model J.M. Duart

In a second phase, the participants of the training actions and the technological tools to be used are defined. The tools must be aligned to the training and learning objectives, and the reality of the institution and the other actors.

After fulfilling these two phases, he suggests starting the valuation of benefits and costs within the organization.

Table 1 shows the proposal of Duart, who suggests to clearly define the company's vision, its goal, how often the evaluation is done in a period of time and which aspects will be included in the assessment.

Josept. M. Duart, in his study, defines two types of potential benefits to quantify, time and costs saving, as well as other indicators that are difficult to be measured, such as innovation, creativity, improvements at work.

$\mathrm{He}$ also defines other benefits that involve even greater complexity to quantify or that are almost impossible to assess, such as satisfaction, happiness and leadership.

These aspects may seem impossible to measure, but the study realize the impact they generate in the business objectives; its impact is even greater than the measurable objectives. This gives us an idea of the complexity involved in quantifying the benefits of a training using e-learning platforms, because the benefits that generate greater impact or might be of interest are practically impossible to determine.

\section{Vann Slyke's Systemic Model}

This model [6] evaluates training programs, assessing a set of characteristics of the actors such as the ones in table 2.

\begin{tabular}{|l|l|}
\hline $\begin{array}{l}\text { Characteristics } \\
\text { of ... }\end{array}$ & \multicolumn{1}{|c|}{ Indicators } \\
\hline The institution & $\begin{array}{l}\text { Ability to implement e-learning } \\
\text { actions. Objectives, economic } \\
\text { capacity. } \\
\text { Infrastructure for action support }\end{array}$ \\
\hline The student & $\begin{array}{l}\text { Interests, expectations and skills. } \\
\text { Self-sufficiency, personal time } \\
\text { management. } \\
\text { Computer proficiency and attitude }\end{array}$ \\
\hline
\end{tabular}




\begin{tabular}{|l|l|}
\hline & $\begin{array}{l}\text { towards technology. } \\
\text { Capacity to solve problems }\end{array}$ \\
\hline The course & $\begin{array}{l}\text { Capacity of e-learning system in } \\
\text { relation to the needs and } \\
\text { methodologies of teaching and } \\
\text { learning }\end{array}$ \\
\hline Learning & $\begin{array}{l}\text { Creating new models of adaptation } \\
\text { of users (students and teachers) to } \\
\text { new environments } \\
\text { Ensuring calm, comfort and ease of } \\
\text { learning. }\end{array}$ \\
\hline
\end{tabular}

Table 2. Vann Slyke's Systemic Model

It must be highlighted the fact that this is the only model that considers the variable student's characteristics like a factor of success in the on-line training [7].

\section{Marshall and Shriver's model of five levels of evaluation}

Marshall Model and Shiver [8] focuses on five levels of action which aims to ensure the knowledge and skills of the participant. It pays special interest in assessing the quality of teaching as a guide for the main protagonist of learning: the student. The five levels are presented in table 3.

\begin{tabular}{|l|l|}
\hline \multicolumn{1}{|c|}{ Level } & \multicolumn{1}{c|}{ Indicator } \\
\hline Teaching & $\begin{array}{l}\text { Projection into technological means and its } \\
\text { different tools, such as e-mail, chat, virtual } \\
\text { classroom. } \\
\text { Material preparation skills, as writing... } \\
\text { Interaction with students, immediate response } \\
\text { to their messages. }\end{array}$ \\
\hline $\begin{array}{l}\text { Course } \\
\text { materials }\end{array}$ & $\begin{array}{l}\text { Student satisfaction in the use of materials. } \\
\text { Relevance, degree of difficulty, interest and } \\
\text { effectiveness. }\end{array}$ \\
\hline Syllabus & $\begin{array}{l}\text { Level } \\
\text { Comparison with other }\end{array}$ \\
\hline $\begin{array}{l}\text { Course } \\
\text { modules }\end{array}$ & $\begin{array}{l}\text { Structure } \\
\text { Order }\end{array}$ \\
\hline $\begin{array}{l}\text { Learning } \\
\text { transfer }\end{array}$ & $\begin{array}{l}\text { Degree to which the learned skills and } \\
\text { knowledge can be implemented in a job }\end{array}$ \\
\hline
\end{tabular}

Table 3. Marshall and Shiver's Model

\section{Kirkpatrick's Model}

Kirkpatrick model [9] evaluates training activities. Although it was introduced over 40 years ago, it remains valid. This model considers four levels and their respective indicators (table 4).

Several studies have been performed upon this model [4], suggesting the application of the last two levels, considering them as providers of further information. The first two levels collect information directly from the courses and their participants, therefore they have a low degree of reliability [4],

For Kirkpatrick Group (One and Only Kirkpatrick company ${ }^{1}$ ) it is essential to continue working on demonstrating the value of training, taking an active part in ensuring that what is learned is applied to the work. From this starting point, a tracking of the expected results must be performed and reported. If training is not contributing to key results of the organization, then the analysis should be oriented to define what needs to be changed.

\begin{tabular}{|c|l|}
\hline Level & \multicolumn{1}{|c|}{ Indicators } \\
\hline Reaction & $\begin{array}{l}\text { Student opinion about their expectations of } \\
\text { the course. Where positive and negative } \\
\text { aspects of course and the appropriateness of } \\
\text { the methodology are collected. }\end{array}$ \\
\hline Learning & $\begin{array}{l}\text { Determine the level of acquired knowledge } \\
\text { and skills. The degree to which students } \\
\text { assimilate the imparted knowledge. }\end{array}$ \\
\hline Transfer & $\begin{array}{l}\text { Contribution of training to improve the } \\
\text { person, his or her work and the organization. } \\
\text { Application of knowledge }\end{array}$ \\
\hline Impact & $\begin{array}{l}\text { Benefits for the performance of the } \\
\text { organization in financial terms }\end{array}$ \\
\hline
\end{tabular}

Table 4. Kirkpatrick's Model

In the last level of this methodology the concept of return on expectations (ROE) arises, an important element in the assessment of e-learning showing its value in terms deemed relevant to the organization.

Both the ROI and ROE are oriented to explain that training is an investment and not an expense. ROE seeks to determine the association and teamwork of all participants, being the training not just an end but a key factor contributing to the goals of the organization.

The return on expectations (ROE) has taken great importance at the time of assessing learning. The reason is that when it is used properly, it allows clearly show the value of training in the terms desired by stakeholders.

The Kirkpatrick group highlights the value of ROE above the ROI because ROE is designed and implemented in partnership with all stakeholders in the organization and it will determine the value of learning.

All the Kirkpatrick's work gave rise to the creation of a model called "New world Kirkpatrick model", applicable to both classroom training and e-Learning (figure 1).

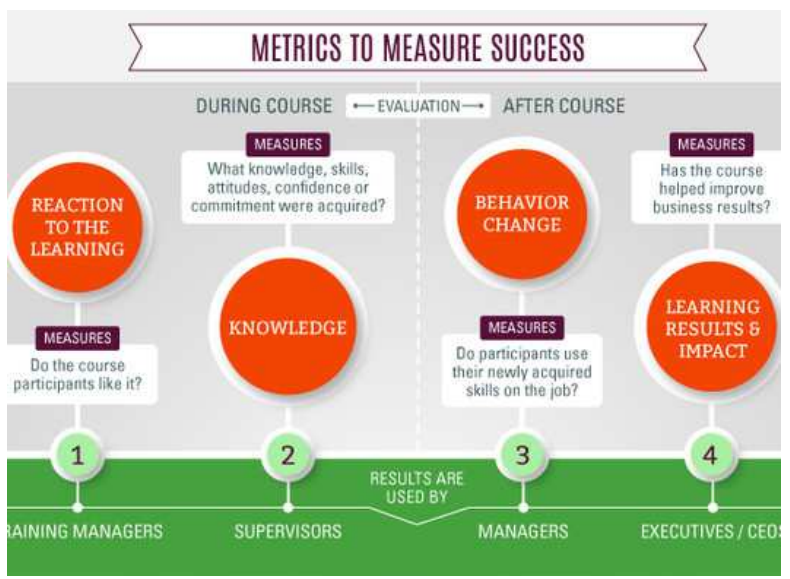

Figure 1. New Kirkpatrick's Model

The application of this model produces relevant information about of the quality of the course, enabling possible immediate 
adjustments on how the instructor teaches, the quality of the materials and the course content, among others.

\section{HYPOTHESIS}

As a result of the analysis of the works discussed in the previous section, several questions arise that would be very interesting to answer:

Is it possible the definition of a simpler and scalable methodology for assessing the return of the investment and the impact in the use of virtual education platforms, to be applied in public universities of Ecuador?

What is the correct procedure for identifying appropriate indicators to assess e-learning, for public universities in Ecuador?

What is the impact on public universities in Ecuador, caused by the missing use of implemented platforms and how its use could support the fulfillment of the corporate goals, improving the teaching - learning processes?

Are there policies, procedures and standards for assessing the ROI and impact of the use of e-learning platforms for public universities in Ecuador?

As hypothesis of this work, we propose that by searching for the answers to these questions and analyzing different aspects it may be possible to establish a model to assess the return on investment that a university makes on e-learning to determine whether it is profitable or not. The hypothesis allows us to define objectives and activities fulfill them:

- Propose a methodology to estimate the profitability and the impact of using online learning platforms in higher education

- Analyze the different techniques used to measure the performance and impact of online education projects and define the main characteristics of the on line teachinglearning processes: analysis of training needs, applied formats and learning and assessment strategies

- Study the current situation of the Faculty of Economics Sciences (FCE), Central University of Ecuador, concerning the utility level of e-learning applications in the teachinglearning process. Design a methodology that allows to determine influential factors for estimating profitability and impact of the use of virtual learning platforms; as an improvement methodology, aligned to learning outcomes and objectives of the organization.

- Apply the methodological proposal for estimating profitability and impact on the FCE at the Central University of Ecuador.

\section{RESEARCH APPROACH AND METHODS}

In the previous sections have been presented different models of evaluation for the teaching-learning processes and the impact of technology on them. Rubio [11] and Garcia [12] analyze the methodologies proposed by Vann Slyke, Marshall \& Shiver, Kirkpatrick and Mathison in order to identify a set of valid indicators to assess the impact of training programs in virtual environments.

The drawback detected in the afore mentioned models is that the indicators are not specifically defined, there are no standards for measurement or for making evidence of the indicators proposed as elements of evaluation.

The work focuses on determining relevant variables that make viable the faithful representation of the factors included in the model, in order to construct an instrument to measure the variables considered appropriate for this model and clearly define standards to take evidence and measurement.

Once defined these variables and incorporated into the model, its properties will be analyzed in order to determine their validity and degree of adjustment to the environment where they are required to apply. Table 5 shows a proposal where relevant characteristics of the models are considered and also some weaknesses to be overcome are detected.

Table 5 shows a first proposal of a model to assess the impact and benefits of working with e-learning tools, considering three basic areas: objectives, benefits and costs, assessed from two perspectives: the organization and participants.

In the proposed model several agents are involved: organization, teachers, course coordinators, student, and so on. For each of them three basic areas are considered: objectives, benefits and costs. To measure each of these axes, a series of indicators are set. The values of these indicators are obtained from different sources: some of them come from the university while others are obtained from surveys on different groups. Finally, the values obtained from the indicators will be compared with the values that determine the achievement of the objectives.

\section{RESULTS TO DATE AND THEIR VALIDITY}

Information about models that evaluate ROI and impact of the use of online training platforms is being collected to establish the research base line. The review has shown that these methods have different approaches, weaknesses, and strengths. A model will be designed with this information.

The research methodology will be based on a survey on the participants in the process (students, teachers, coordinators and authorities).

The results of the survey make up the starting point to observe and describe what is happening with the e-learning environment, to identify existing problems and to define solutions, to measure limitations, to concretely define the results to be obtained, to determine the quality level of the course and the learning results, and to identify the extent to which the new knowledge is applied.

If it is possible to determine the impact of investment in elearning at a university and this is too low,, maybe the e-learning methodology is not being applied properly. As the proposed model analyzes different aspects of the involved agents, it can be used as feedback to improve the implementation of e-learning methodologies.

Finally, the proposed model provides a set of quantified elements that ensure the viability of obtaining values of ROI and ROE. 


\begin{tabular}{|c|c|c|c|}
\hline \multicolumn{4}{|c|}{ PROPOSED EVALUATION MODEL } \\
\hline Design & Actors & $\begin{array}{l}\text { Instrument } \\
\text { Preparation } \\
\text { Guide }\end{array}$ & $\begin{array}{l}\text { Assessment } \\
\text { Instrument }\end{array}$ \\
\hline \multirow[b]{2}{*}{ Objectives } & $\begin{array}{l}\text { Organization } \\
\text { (Training } \\
\text { Action) }\end{array}$ & $\begin{array}{l}\text { Define objectives } \\
\text { based on } \\
\text { organizational } \\
\text { strategy }\end{array}$ & \multirow{2}{*}{$\begin{array}{l}\text { Document } \\
\text { containing } \\
\text { the } \\
\text { description } \\
\text { of the } \\
\text { objectives. } \\
\text { Description } \\
\text { of expected } \\
\text { results in a } \\
\text { defined } \\
\text { period of } \\
\text { time }\end{array}$} \\
\hline & $\begin{array}{l}\text { Participants } \\
\text { (students, } \\
\text { tutors and } \\
\text { course } \\
\text { coordinators } \\
\text { and } \\
\text { institutional) }\end{array}$ & $\begin{array}{l}\text { Define learning } \\
\text { objectives based } \\
\text { on the interests } \\
\text { and needs of } \\
\text { participants }\end{array}$ & \\
\hline \multirow[t]{2}{*}{ Benefits } & Organization & $\begin{array}{l}\text { Determine the } \\
\text { expected benefits } \\
\text { - Quantifiable } \\
\text { - No quantifiable } \\
\text { Quantify the } \\
\text { expected results } \\
\text { Qualify the } \\
\text { expected results. }\end{array}$ & $\begin{array}{l}\text { List of } \\
\text { concrete } \\
\text { benefits } \\
\text { expected to } \\
\text { be obtained } \\
\text { expressed as } \\
\text { indicators of } \\
\text { improveme } \\
\text { nt. }\end{array}$ \\
\hline & Participants & $\begin{array}{l}\text { Define satisfaction } \\
\text { levels expected for } \\
\text { each of the } \\
\text { participants. }\end{array}$ & $\begin{array}{l}\text { List of } \\
\text { benefits and } \\
\text { achievemen } \\
\text { ts expressed } \\
\text { as } \\
\text { performanc } \\
\text { e indicators. }\end{array}$ \\
\hline \multirow[t]{2}{*}{ Costs } & $\begin{array}{l}\text { Organization } \\
\text { (Training } \\
\text { Action) } \\
\end{array}$ & $\begin{array}{l}\text { Define costs for } \\
\text { the organization }\end{array}$ & $\begin{array}{l}\text { List of the } \\
\text { training } \\
\text { costs }\end{array}$ \\
\hline & Participants & $\begin{array}{l}\text { Define costs for } \\
\text { participants }\end{array}$ & $\begin{array}{l}\text { ROI } \\
\text { calculation }\end{array}$ \\
\hline
\end{tabular}

Table 5. Proposed Model

\section{DISSERTATION STATUS}

Currently, information is being collecting on various existing methodologies to design a model that assesses the impact of elearning. For this purpose, we are also preparing questions to make up the surveys that serve as a basis to analyze the current situation in the Central University of Ecuador.

The study has confirmed that these methodologies have different approaches, strengths and weaknesses, therefore the proposed model should consider the relevant and positive aspects of the analyzed models and try to adjust the lacking issues.

An important aspect to keep in mind is that the Organization in which the model is applied will be the one that defines the baseline to determine the parameters to be used in the methodology. For this reason, the proposed model must be flexible and adaptable to the study environment.

The main idea is to apply the proposed instrument in Ecuadorian public universities, taking the Central University of Ecuador as a study case. The collected data will determine if this methodology meets the necessary elements that allow to observe the university and their level of use of learning platforms.
Subsequently, the objective is to create a specific, scalable, simple and progressive framework, to measure the return on investment in e-learning and its impact.

Consequently, it is necessary to contribute with a specific framework for public universities in Ecuador, so that the benefits gained by involving Information Technologies as a key instrument of the teaching-learning process are known.

\section{CURRENT AND EXPECTED CONTRIBUTIONS}

The analyzed models assume a starting point for this study. One of the important conclusions obtained from these models is that it is necessary to clearly determine what aspects are to be evaluated. Some of these aspects to be assessed: student satisfaction, their learning level after using the learning tools, the applied teaching strategies, the actual transferred knowledge and its impact within the organization.

Another question is who will evaluate. The answer is clear: people involved in the assessment process: students, tutors and institutional coordinators, who will be called participants. Finally, it should be also determined when, how and how often the evaluation process will be performed [13].

This proposed research is expected to contribute a proposal for an assessment methodology of the results generated from the use and application of e-learning platforms. The study will reveal the effectiveness of the model related to the institutional impact. It will also allow identifying the key elements to be considered in a process of e-learning with respect to management, design and implementation of the program to ensure a positive impact within the institution.

\section{REFERENCES}

F. J. García-Peñalvo and A. M. S. Pardo, "Una revisión actualizada del concepto de eLearning. Décimo Aniversario/An updated review of the concept of eLearning. Tenth anniversary," Teoría de la Educación; Educación y Cultura en la Sociedad de la Información, vol. 16, p. 119, 2015. G. Conole, "Reviewing the Trajectories of Elearning," Towards new horizons in Higher Education, 2014.

[3] B. F. a. M. Fetaji, Model For Planning Developing And Evaluating E-Learning Software Solutions, 2010.

[4] D. Stoel and R. van Leeuwen, "Guide for Training Consultants: Quality of e-learning and evaluation ROI," ed: Tartu: ELQ-SMEs Project, 2007

[5] J. M. Duart, "ROI and e-learning: beyond benefits and costs, "Document Online: www.uoc.edu/web/esp/art/uoc/duart0902/duart0 902 . html, 2002.

[6] C. K. Van Slyke, M. \& Belanger, F., "Identifying Candidates for Distance education: A telecommuting per- spective. ," America's Conference on In- formation Systems. Baltimore. , 1998.

[7] A. C. Fantini, B. Radice, and E. Bocca, " Formative assessment approaches to e-learning, 
"in First Congress on Information Technology and Communication in Science Teaching, 2005.

[8] A. C. Fantini, B. Radice, and E. Bocca, " Proposal evaluation of university teaching in virtual learning environments, "Spanish Journal of Education, pp. 261-279, 2010.

[9] C. Biencinto and R. Carballo, " Proposal evaluation of university teaching in virtual learning environments, "Spanish Journal of Education" 2004.

[10] M. L. Jiménez and R. Barchino, " Evaluation and implementation of an evaluation model of training activities, "Competitiveness, 2011.

[11] M. J. Rubio, "Focus and models of evaluation of the e-learning," ed, 2003.

[12] J. García Mestanza, " Causal Model of Teaching Quality Factors of the University of Malaga in Virtual Learning Environments."

[13] P. e. a. Pineda, "How the training is evaluated in organizations?," pp. 126 - 127, 1999. 